\title{
UNDERSTANDING ORGANIZATIONAL CULTURE IN A SMALL FAMILY FIRM
}

Artigo recebido em: 02/09/2014. Artigo aprovado em: 26/06/2015.

Gustavo José da Nóbrega Danda - Universidade de Brasília ${ }^{1}$ Denize Grzybovski - Universidade de Passo Fundo ${ }^{2}$

\begin{abstract}
The purpose of this study is to investigate the characteristics of organizational culture that fosters entrepreneurship in family firms. The entrepreneurial process is viewed as radical change in family firms due to emotions related to change in this kind of organization, which are more intense than nonfamily firms and makes the organization behaves the same way of previous generation. The culture of family firm Alfa is analyzed through the model of Hall, Melin and Nordqvist (2001) which classifies family business culture according to the fact that it is dominated by one or several family members, the degree of culture explicitness and cultural openness. A single case study was conducted and semi-structured interviews were made with family and non-family members of the family firm Alfa. It was concluded that, despite the fact the employees feel comfortable to express their ideas and critics, the values and norms are not clearly stated and the culture is dominated by the influence of the founder. These last two characteristics damage the entrepreneurial process in the family firm analyzed.
\end{abstract}

Keywords: Organizational Culture; Entrepreneurship; Family Firm

\section{A COMPREENSÃO DA CULTURA ORGANIZACIONAL EM UMA PEQUENA EMPRESA FAMILIAR}

Resumo: O objetivo deste estudo é investigar as características da cultura organizacional que fomentam o empreendedorismo em uma empresa familiar. $O$ processo empreendedor é considerado como uma mudança radical em empresas familiares em virtude das emoções relacionadas com o processo de mudança nessas organizações, que são mais intensas do que em empresas não familiares, fazendo com que a organização se comporte do mesmo modo da geração anterior. A cultura da empresa familiar Alfa é analisada por meio do modelo de Hall, Melin e Nordqvist (2001), que classifica a cultura organizacional da empresa familiar de acordo com o fato de que ela é dominada por um ou vários membros da família, o grau de abertura e de visibilidade da cultura organizacional. Um estudo de caso

\footnotetext{
${ }^{1}$ E-mail: gustavojdnobrega@gmail.com

2 Endereço: Rua Uruguai, 1391, Apto. 402, Passo Fundo (RS), CEP 99010-111

E-mail: gdenize@upf.
} 
único e entrevistas semiestruturadas foram realizados, tanto com membros quanto com não membros familiares da empresa familiar Alfa. Concluiu-se que apesar do fato de os funcionários se sentirem confortáveis para expressar suas ideias e críticas, os valores e as normas não estão claramente definidos e a cultura é dominada pela influência do fundador. Estas duas últimas características prejudicam o processo empreendedor na empresa familiar analisada.

Palavras-chave: Cultura Organizacional; Empreendedorismo; Empresa Familiar

\section{Introduction}

Family businesses are an important source of economic development and growth since they represent the highest proportion of business in the world (LIN, 2012). In Italy, Spain and Brazil, over 90 percent of the businesses are controlled by families (HABBERSHON, 2006). Moreover around 60 percent of all European firms are family (EUROPEAN COMISSION, 2009).

According to Sharma and Nordqvist (2008), the interest in family business research has increased because researchers recognized the unique context of family firms and their distinctive resources and capabilities that generate competitive advantage. In this line, the purpose of this study is to investigate the characteristics of the organizational culture that foster entrepreneurship in family firms.

It is important to say that a single and a consensual definition of family business do not exist (SHARMA, 2004). However, this doesn't mean that there is no definition - rather there are several. The concept of family business, which is adopted in this study, was proposed by Westhead and Cowling (1998) who said that family firms are one family group who controls the firm through a clear majority of the ordinary voting shares, the family is represented in the management team and the leading representatives of the family perceive the business to be a family firm.

The positive aspect of this definition is that it places emphasizes not just on technical definitions of family business, such as controlling voting shares or the number of family members involved in the business, but also on psychological issues such as how family members perceive their business, which is important due to the fact that it can have an impact on the level of commitment of each family member towards the business. 
The concept of family adopted in this paper was proposed by Grzybovski and Lima (2004, p.7) who define as a "group of people linked by parental relationships established not just by genealogical, biological and social ties, but also by the union of couples with children from other marriages".

Family Business have been characterized with traditions that are against entrepreneurship (HABBERSHON; WILLIAMS, 1999) since the next generation run the business in the same way of the previous generation due to strong tradition and values (HALL; MELIN; NORDQVIST,2001). Despite the fact that entrepreneurship has become one of the most common topics in managerial literature, this term has been used for almost 200 years and there still remains considerable debate related to its meaning (MORRIS; KURATKO, 2002).

The definition of entrepreneurship that it is employed in this study was proposed by Wiklund (1998, p. 258) as "taking advantage of opportunity by novel combinations of resources in ways which have impact on the market". It was chosen this definition since it focuses on firms resources, which are one of the variables of this study, as a way for the organization to be more entrepreneurial.

The organizational culture is a key element in the entrepreneurial process since, according to Hall, Melin and Nordqvist (2001), the culture is what makes possible entrepreneurship in the first place and it is necessary that family firms continuously check and, if necessary, change old patterns of culture in order to cope with the turbulence and uncertainty of the environment. The same authors also mention that "whereas some cultural patterns tend to preserve the traditional way of doing business other tend to facilitate entrepreneurial change" (HALL; MELIN; NORDQVIST, 2001, p. 201).

Due to the important role that family firms play in the economics of many countries, the fact that entrepreneurship is important for value creation and the role that the organizational culture plays in promoting change that fosters the entrepreneurial process, it is essential that the culture has the requirements to promote the growth of family business (CHUA; CHRISMAN; SHARMA, 2003; BARNETT; KELLERMANNS, 2006; EUROPEAN COMMISSION, 2009; MELIN, 2009; LIN, 2012). In other words, since organizational culture is one of the components of corporate entrepreneurship, it is necessary that the culture helps 
family firm to keep up with the change, renewal and flexibility that leads to future growth (BURNS, 2005).

It should be mentioned that the field of Family Business is still in its infancy in Brazil. Martins, Maccari, Campanario and Almeida (2008) state that from the period of 1996 to 2005, from the 3,825 articles published at the Annual Meeting of PostGraduate Programs of Business Administration (ENANPAD), just 14 analyzed management topics in the context of family business. Borges, Brito and Lescura (2012) state that succession is the most prevalent issue (22.9\%) in Brazilian journals, among subjects normally discussed in the family business literature, followed by strategy (8.0\%), governance (8.0\%) and organizational culture (6.0\%).

Regarding the organizational culture in Brazilian family firms, it is necessary to highlight the studies of Silva Junior, Silva and Silva (2013), which analyses the value systems that guide the controlling family in management decisions, and the study of Lopes, Carrieri and Saraiva (2013), that reveals strategies of the family to transmit values of the business to the next generation and, as a consequence, creates a positive environment for the next generation to participate in the business in their early years.

Considering the significance of family firm population in most countries and few previous studies in this field in Brazil, specifically when involves topics such as entrepreneurship and organizational culture, this paper aims to fill this gap.

This article is structured in two parts. This first part the first part is this introduction. The second part is divided into three sections. The first one presents research models in family business with a major concern to show family and business as complementary and not as antagonistic systems as it was described by earlier researches in this field. The second part shows the model of Hall, Melin and Nordqvist (2001), which discusses the characteristics that organizational culture in family business must present in order to promote entrepreneurship. The last part of this section presents Habbershon (2006) studies about entrepreneurship in family business context. The third section describes the methods applied in this paper followed by the results, analysis and the conclusion. Finally, the second part of this paper is the frame of reference. 


\section{Research models in family business}

In order to understand the nature and the unique characteristics of family firms, some theoretical models have been developed in this field. The Two Circle Model, which considers the household-enterprise complex made by the overlapping of the firm and the business, was one of the first attempts to investigate this phenomenon (RÖMER-PAAKKANEN, 2002). In addition, Kenyon-Rouvinez and Ward (2005) mention that the fundamental dilemma faced by family business stems from the overlapping or sometimes a total amalgamation of the family and the business since, on the one hand, families are governed by equality, inclusiveness and caring feelings, while, on the other hand, businesses are governed by meritocracy, selectivity, and critical analysis.

The drawback of the Two-Circle Model consists on the fact that many of the major dilemmas faced by family enterprises have their origin not from the distinction between the family and the business but from the owners and the managers (GERSICK et al., 1997). This different perspective of understanding the householdenterprise complex brought about the Three Circle Model, which is represented by the subsystems family, management and ownership, as it can be seen in the figure below (TAGIURI; DAVIS, 1996).

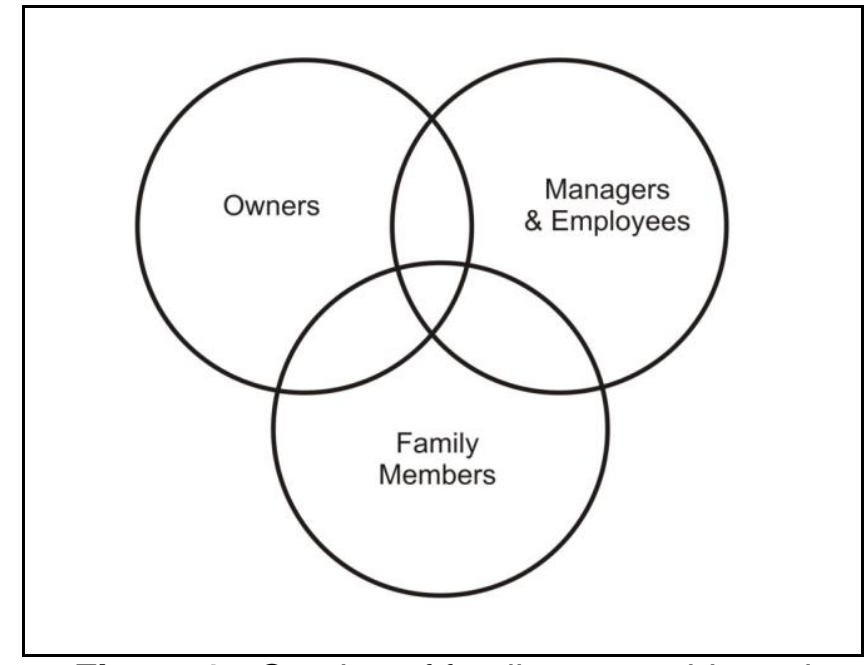

Figure 1 - Overlap of family, ownership and management groups

Source: Adapted from Tagiuri and Davis (1996). 
Chua, Chrisman and Sharma (2003) claims that the unique characteristics of family firms are a result of the involvement of family through ownership, governance and management and, as a consequence, the model of Tagiuri and Davis (1996) is suitable to visualize the specific features of family firm.

Based on the Three-Circle Model, Poza (2007) offers a classification of family firms according to their propensity to have family-first, ownership-first or management-first perspective on issues. In his categorization, a family-first perspective is the type of family business that exists primarily for the purpose of the family. In consonance with this approach, secrecy is often paramount since the lack of transparency will allow compensating family members beyond what would be considered as reasonable.

In the second type, management-first perspective, Poza (2007) claims that family firms are characterized by an emphasis of management issues in the business. As a result, it is required from family members working experience outside the business in order to be involved in the business. Further, in this kind of family firm, the measure of performance is the same for family and non-family members. Finally, the business is considered by the family as a productive asset, which means that there is not a strong commitment of the business to continue to the next generation.

In the last category, ownership-first perspective, Poza (2007) argues that family firm is oriented towards shareholder value, earnings growth rates, debt/equity and debt/asset ratios. In addition, family shareholders who are not involved in the business or who have a little knowledge of the business can prevent the effective operation of the business. As a consequence, these family members can make family firm lose one of its unique characteristics and advantage which is patient capital, or investing in the business for the long run.

It has been said that the fundamental issues for understanding family business such as founder transition, business continuation, succession and life cycles are located in the nexus of the overlapping areas of the three circles model (HOY; VESSER, 1994 cited in HABBERSHON; WILLIAMS, 1999). The effective management of the family or the business system has been considered by scholars 
in the field of family business as a crucial issue for the success of family firms (OLSON et al., 2003).

Gersick et al. (1997) present a modified version of the Three Circle Model, as it can be seen in the Figure 2, in which each dimension is divided into different stages. The ownership axis is comprised by four stages: controlling owner, sibling partnership, cousin consortium and distant relatives. The management or business axis goes through the four stages - start-up, growth/formalization, maturity and decline/regeneration. The family dimension is also analyzed in four stages as the family evolves over time: young family business, entering the business, working together and passing the baton.

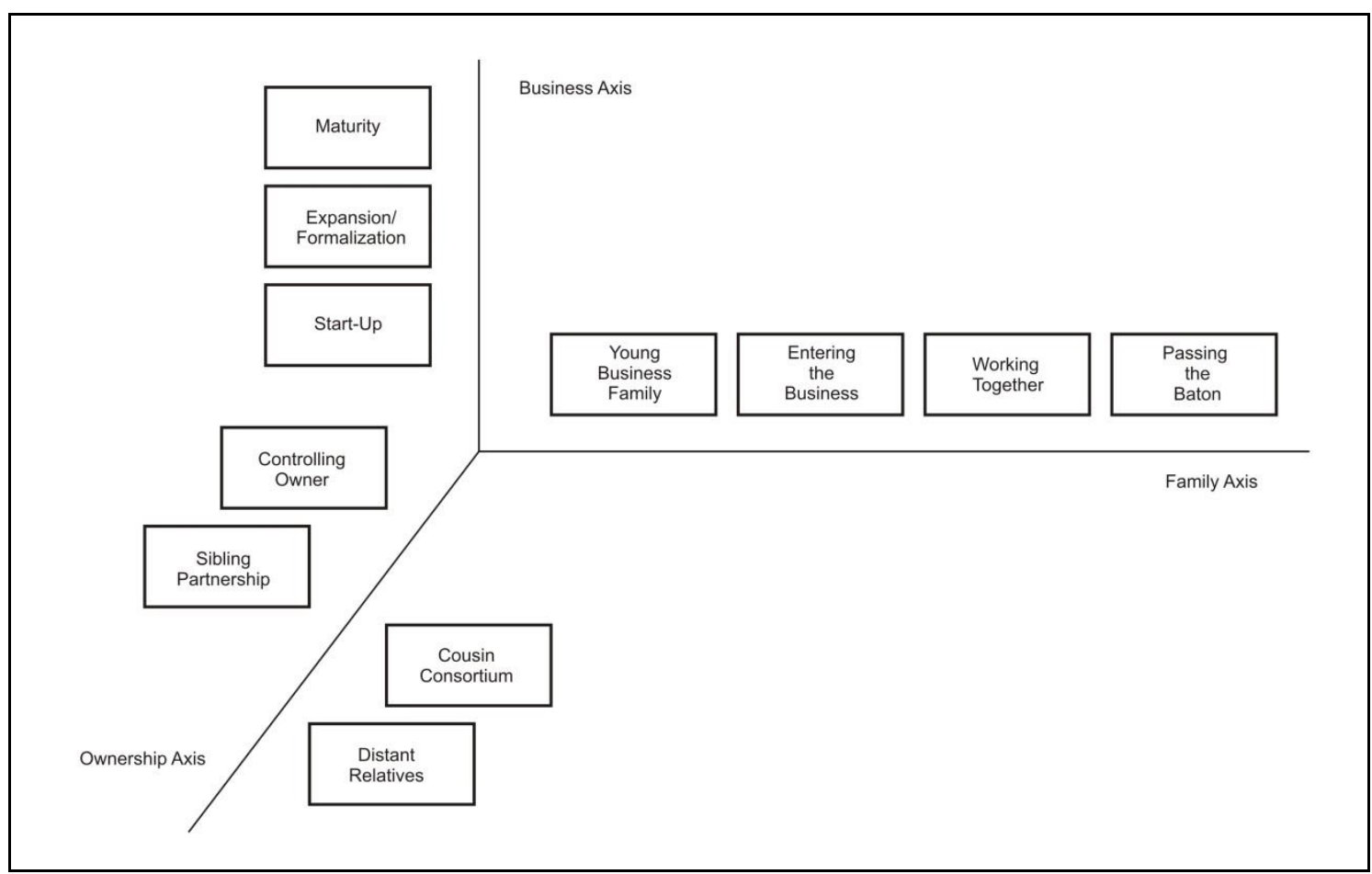

Figure 2 - The Three-Dimensional Developmental Model.

Source: Gersick et al., 1997.

The Three-Dimension Development Model proposed by Gersick et al. (1997) to investigate the organizational development of family firms promotes reflections about the complexity of relations (socials, sex and generation), the dynamics of the systems (social and organizational) and their impact on organizational culture. 


\section{Culture in family business}

One of the typical characteristics of family firms is the organizational culture. Cornwall and Perlman (1990) define culture as "an organization's basic beliefs and assumptions about what the firm is about, how its members behave, and how it defines itself in relation to its external environment" (cited in BURNS, 2005, p. 104). In addition, Hall, Melin and Nordqvist (2001, p. 195) mention that "the dominant culture in a family firm is a result of values, beliefs and goals rooted in the family, its history, and present social relationships".

One of the main stakeholders that influence the culture in a family business is the founders and this can be explained due to their long tenure and centrality of their position which affects not just the culture but also the performance, during and beyond their tenure, as it was investigated by many different scholars in this field (KELLY; ATHANASSUIY; CRITTENDEN, 2000; ANDERSON; REEB, 2003).

The organizational culture in a family business should also be analyzed according to the different stages that family firms can be in their ownership life cycle. This analysis is relevant since the values, traditions, norms and beliefs, components of organizational culture, which support and encourage the development of the business in one stage of the ownership life cycle, such as the controlling owner, can be inappropriate and inhibit the development of the organization in another stage, such as sibling partnership.

Kenyon-Rouvinez and Ward (2005) bring up that the first stage, controlling owner, is characterized by authoritarian system where decision making process is fast but it can be flawed. In the second stage, sibling partnership, there is an intense and volatile relationship among family member and consensus decisions. In the last phase, cousin confederation stage, is adopted a more democratic decision making style and the development of processes and rules are required in order to take into account the opinion of all individuals involved in the business.

The culture of an organization must be adapted as the family business change not just in terms of ownership but also in size. In line with such thinking, Burns (2005) mentions that growth oriented firms are initially characterized by an 
autocratic or dictatorial leadership style, which is one aspect that reflects the culture of an organization, but as the firm grows a more consultative style is developed. Moreover, Burns (2005, p. 105) brings up that language is one of the key elements of culture since "it transmits the view that the group has to itself and the world, but because the words themselves help shape people's beliefs".

The culture in a family firm must also be investigated according to the overlapping between the business and the family. In this way, Poza (2007) points out that the family values and rules influence the decision making process and the behavior of the firm, as well as the business values and rules may impact the behavior in the context of the family.

Poza (2007, p. 28) introduces the term cultural blur to refer to the slight differentiation that exists in family business "[...] between assumptions that go into decision making depending on whether the issue is family, ownership or businessmanagement issue". The same author continues to explain how this relationship influences both systems by stating that love in the family may be reflect in strong commitment to quality and customer service in the business, while a family value of independence may be traduced in the business into risk-management.

The organizational culture should also be investigated according to the external environment. In this line, the unpredictable and uncertain environment in which firm operates requires for managers to constantly question if the culture meets the environmental demands. In family business, the change process in an organizational culture is a special challenge since these firms are characterized by strong emotions. In this sense, Poza (2007) suggests that organizational culture need to be flexible, adaptive and agile due to the fact that the strong culture which is an advantage of family firm can also be at the same time a negative aspect since it can make difficult for the firm to adapt to environmental changes.

In agreement with Zahra, Hayton and Salvato (2004), organizational culture is an important strategic resource for family firms to achieve competitive advantage by promoting entrepreneurship. Hall, Melin and Nordqvist (2001) have investigated three dimensions of organizational culture which are related to entrepreneurial process. The extent to which the culture can be open or closed is one of these dimensions. 
According to these authors, an open culture exists when "individuals do not hesitate to express their criticisms, to question and to state ideas and proposals concerning different aspects of the organization", while a close culture occurs when "individuals in the organization feel discouraged to make suggestions or to criticize or, in other ways, challenge existing values, beliefs and routines" (HALL; MELIN; NORDQVIST, 2001, p. 202).

The second dimension classifies the culture as explicit or implicit. Hall, Melin and Nordqvist (2001) mention that an explicit culture means that the organizational norms, beliefs and assumptions are clear and outspoken whereas an implicit culture is characterized by values, norms and beliefs which is not expressed.

In the last dimension, the same authors claim that the organizational culture in a family can be one family member when the culture is reflected very much by the influence of just one person, the founder, and several family members where the values, beliefs and norms are influenced by different family members (HALL; MELIN; NORDQVIST, 2001). These three dimensions of the organizational culture can be visualized in the figure 3 :

One Family Member

Several Family Members

\begin{tabular}{|c|c|c|c|c|}
\hline & Closed & Open & Closed & Open \\
\hline Implicit & 1 & 2 & 3 & 4 \\
\hline Explicit & 5 & 6 & 7 & 8 \\
\hline
\end{tabular}

Figure 3 - Conceptualization of Family Business Culture.

Source: Hall, Melin and Nordqvist (2001).

Hall, Melin and Nordqvist (2001, p. 202), cite that "different combinations of the three dimensions constitute different cultural patterns. Some cultural patterns tend to preserve the traditional strategic way of doing business, whereas others tend to facilitate entrepreneurial processes". In order to encourage entrepreneurship and to foster change in a family business, the culture must be open and explicit. It's also important to mention that an entrepreneurial organization is very similar to a learning 
organization in which culture encourage and foster learning through the whole organization (BURNS, 2005).

\section{Entrepreneurial process in family business}

The Resource-Based View (RBV) has been used by many scholars (HABBERSHON; WILLIAMS, 1999; SIMON; HITT, 2003; POZA, 2007) for understanding the unique characteristics and the competitive advantage of family firms. Wernerfelt (1984) argues that the terms resources and capabilities are defined in several different ways and there is no consensus on the proper terminology. The concept of capabilities adopted in this study was suggested by Makadok (2001, p. 389), who defines as "[...] special type of resource - specifically, an organizationally embedded nontransferable firm specific resource whose purpose is to improve the productivity of other resources" (as cited by HABBERSHON et al., 2003, p. 459).

Habbershon and Williams (1999), after conducting a review in the literature, classify the resources in family firms into four categories, which are: physical capital resources (plant, raw materials, cash, access to capital, intellectual property), human capital resources (skills, knowledge, training, relationships), organizational capital resources (competencies, control, policies, culture, information, technology) and process capital resources (knowledge, skills, disposition and commitment to communication, leadership and the team).

The heterogeneous resources and capabilities can be a source for organizations to achieve sustainable competitive advantage when they are valuable (help the organization to implement its strategy effectively and efficiently), rare (resources are not shared by a large number of competitors), hard to copy (competitors cannot merely duplicate them) and no substitutable with other resources (BARNEY, 1991).

One of the possible explanations for Habbershon and Williams (1999) have used the resource-based view in their researches can be attributed to the idiosyncratic bundle of resources that family firm posses due to the systematic interaction of the family, the business and individuals. In this sense, family firms are 
best analyzed through the specific complex, rich and intangible resources that are unique to the enterprise-household complex.

In line with such thinking, Poza (2007, p. 14-15) mentions some of these unique resources that can create competitive advantage in a family firm such as:

[...] overlapping responsibilities of owners and managers, along with small company size enable rapid speed to market; concentrated ownership structure leads to higher overall corporate productivity and longer-term commitment to investment in people and innovation.

In order for firms to be more entrepreneurial, it is necessary to focus on developing their internal core competencies and matching them with market opportunities (HABBERSHON; PISTRUI; MCGRANN, 2001). For family businesses, this means that they have to focus on developing distinct familiness which are defined "[...] as the unique bundle of resources a particular family firm has because of the systematic interaction between the family, its individual members and the business" (HABBERSHON; WILLIAMS, 1999, p. 11).

In addition, the familiness can be classified in two categories:

[...] distinctive familiness to refer to the component of a firm's familiness that provides them with a potential advantage and allows them to deliver offerings that other firms cannot match and customers preference and constrictive familiness when these resources do not provide an advantage for the business (HABBERSHON; WILLIAMS, 1999, p. 13).

Habbershon (2006) classifies the entrepreneurial capabilities in family firm as (1) opportunity seeking, (2) insight bursting, (3) decision making, (4) bootstrapping, (5) venture financing, (6) team building, (7) habitual entrepreneur and (8) entrepreneurship reproducing.

The same author has associated opportunity seeking with networks and tacit knowledge as resources that can help family firms to identify new opportunities. Networks in family firms are characterized by strong kinship ties (POZA, 2007), while tacit knowledge is normally derived from the experience of an individual (MORRIS; KURATKO, 2002). Insight bursting is related to entrepreneurial alertness which is the ability to notice things without engaging in deliberate search (BARRINGER; 
IRLEAND, 2006). The resources that can foster this capability in family firm are organizational governance, decision making and tacit knowledge.

Decision making is referred by Habbershon (2006) as one of the most important entrepreneurial capabilities that can bring competitive advantage to family business since the tacit knowledge, operational process capabilities, intuitive insight and actions that are based in family business in simplified strategic thinking (heuristic) helps the entrepreneurial decision making process.

Bootstrapping is defined by Habbershon (2006, p. 89) as "discovering, mobilizing, or leveraging resources and capabilities currently controlled by the entrepreneur" as a key success factor in the entrepreneurial process and network. According to the same author, the resource associated with this capability is bootstrapping.

The financial decision process in family firms has some unique features since the way that families leverage their social network can create an advantage in obtaining funding and the allocation of resources. Moreover the owners/manager decision making and intuitive-based tacit knowledge can bring advantages to family firm in leveraging financial resources (HABBERSHON, 2006).

Johannisson (2004) concluded that human capital is the most important resource for family business and this can be explained by the fact that family firms are a collection of individual who live and work together. Habbershon (2006, p. 91) states that "families also have the potential to become transgenerational teams and to continue their entrepreneurial family vision and legacy across many generations". The same author mentions that families are often habitual entrepreneurs which signify that family members are normally individuals who hold or have held ownership stake in two or more business (UCBASARA; WESTHEAD; WRIGHT, 2006) and the resources associated with this capability are mentoring relationship and business portfolio.

The last capability is entrepreneurship reproducing. Families are naturally great reproducers and extenders of market since family networks and portfolio businesses are important resources that help family firms bring to market products, services and structures very similar to the one that already exists (HABBERSHON, 2006).

DANDA, G. J. N.; GRZYBOVSKI, D. Understanding organizational culture in a small family firm. Revista de Empreendedorismo e Gestão de Pequenas Empresas, v.4, n.2, 2015 
Family Business is considered a special context to investigate organizational phenomena such as culture and entrepreneurship (HABBERSHON, 2006). The Three Circle Model has been widely used in the literature to understand how the overlap between the family, business and ownership can impact the day-to-day activities in family firms. The organizational culture is one of the distinctive characteristics of these firms (POZA, 2007).

The Model of Hall, Melin and Nordqvist (2001) takes into account the particularities of family firm such as the role of a member who strongly influences the culture (in many cases the founder) in the entrepreneurial process. The relationship between culture and entrepreneurship stems from the fact that is the organizational culture that defines what kind of movements that a firm can make (HALL; MELIN; NORDQVIST, 2001).

In this way, entrepreneurship can be considered a cultural phenomenon that reflects the predisposition of family business to be involved in entrepreneurial activities. It is used the RBV with the objective of identifying the internal resources that fosters the entrepreneurial process in Family Firm Alfa. More specifically, it is applied the concept of familiness to analyze the relationship between resources and entrepreneurial capabilities (HABBERSHON; WILLIAMS, 1999).

\section{Methodological procedures}

This study is classified as longitudinal and in depth case study. The investigation of a case study in depth can bring some advantages in the way that the researchers can gain a more accurate and clear picture of a respondent's position and this is possible by open-ended question since respondents are free to answer according to their own thinking (GHAURI; GRØNHAUG; KRISTIANSLUND, 1995).

The case study was chosen as the research strategy of this investigation due to the following reasons: first of all, the unit of analysis of this study is a single organization where entrepreneurship can be considered as a kind of organizational behavior. Moreover, the organizational culture, one of the variables under investigation in this study, is difficult to quantify. In order to classify the culture of the 
family firm analyzed in this study, according to the model presented by Hall, Melin and Nordqvist (2001), it is necessary to see how members of this organization interprets the degree of openness, explicitness and dominance of the family firm by the founder or other members of family.

The analytical model employed in this study was developed by Hall, Melin and Nordqvist (2001), as it was shown in Figure 2. Through a combined analysis of empirical observations and theoretical framework, the authors identify a set of dimensions that are useful to comprehend how different cultural patterns have a positive or negative impact on the entrepreneurial process.

Depending on their cultural characteristics, family firms can fall into different positions in the model. As it was mentioned, these cultural characteristics are analyzed in three groups: (a) the degree of openness; (b) the degree of explicitness; (c) if the family firm is influenced by one or several family members.

It is important to mention that the model is also used to analyze the dynamic nature of organizational culture, in other words, how the organization move in the model as their cultural pattern change.

Face to face interviews were conducted with four family members (the founder, the founder's wife, the founder's son A and the founder's son B) and one non-family member employee (employee $\mathrm{C}$ ). The fact that the wife of the founder was one of the family members interviewed reflects a trend in the study of family business which is not just taking into account the entrepreneur but also the whole family in the investigation. From the three non-family members working in the business, employee $\mathrm{C}$ was the only interviewed due to the fact that he was involved since the foundation of this organization.

Semi-structure interview was chosen as the method since it gives the researcher the freedom to ask more questions during the interview in order to understand the phenomenon (WELMAN; KRUGER; MITCHELL, 2005). The interviews were pre-schedule regarding the day and the time and it lasted on the average 30 minutes. Despite the fact that there were some questions beforehand, the respondents were encouraged to discuss about the family firm, the stakeholders of this company such as customers, suppliers and other companies, their experiences and other issues that were brought up naturally during the conversation. 
The interviews were concentrated on the following topics: a) the main resources of this family firm that foster entrepreneurial capabilities; b) the organizational change process in this family firm and (c) the role of each family member in the change process in order to identify cultural characteristics of the family firm that can fit one of the positions of the model presented by Hall et al. (2001).

In the analytical process, these topics were considered as analytical categories, as it is recommended by the technique analysis of categories proposed by Bardin (2009) in the use of the method content analysis.

\section{Results and Analysis}

There are two businesses owned by the entrepreneur of family firm Alfa which constitute a business portfolio. The entrepreneur of this family firm is a minority shareholder of a transportation company and owns some of the buses of this company which offers services in Mexico. The second business, the one which is going to be investigated in this study, is a workshop, founded in 2003.

The two main services offered are electrical and mechanical systems. These services are considered as the core competencies of the business. Additional services that could be necessary are outsourced by the workshop. It should be emphasized that the only costumer of this organization is the buses from the transportation company that the entrepreneur is a minority shareholder. This organization has had other clients, occasionally. In this way, it is possible to realize that the workshop is very close related to the other business that the founder is also involved.

The workshop started with five employees, where two of them are family members. Currently, this family firm presents the same size in terms of number of services offered and employees as it started in 2003.

One of the typical characteristics of family firms which is the overlapping of family, ownership and management is noticed in the organization under this investigation. Furthermore, this feature is even stronger in small family firm (NORDQVIST; MELIN, 2002), which is the case of firm Alfa. The family is composed 
by four members: (1) the founder of the business; (2) the founder's wife; (3) founder's son $A$; (4) founder's son B. In this organization, there is an overlapping of roles due to the fact the founder of the family firm and founder's son $A$ are, at the same time, family members and part of the management team, besides the fact that they own the business. The different roles that the family members occupy in the business can be visualized through the Three Circle Models.

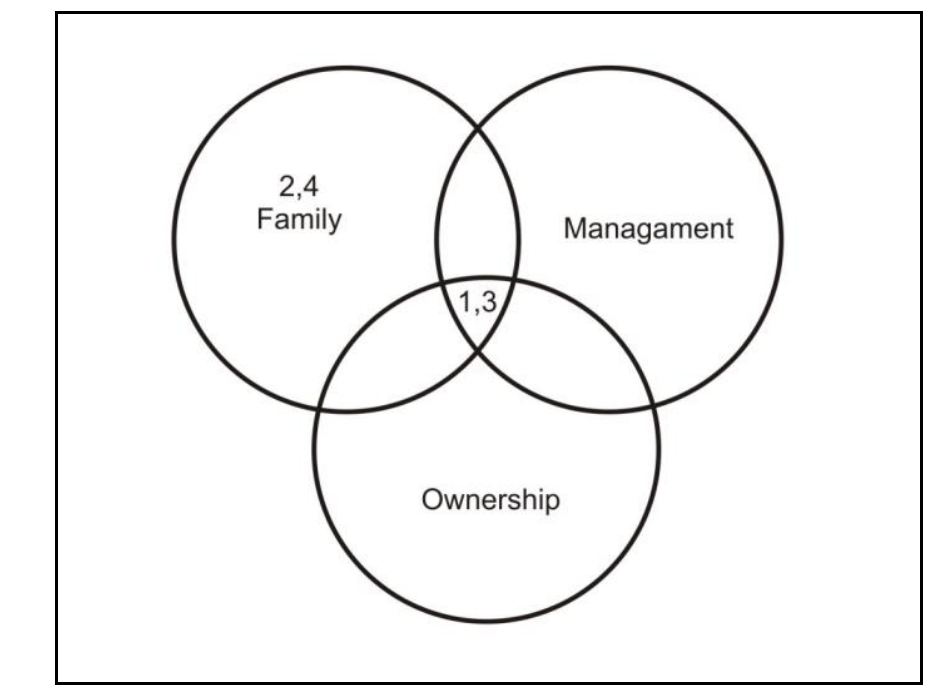

Figure 4 - The position of family members in the Family

Firm A.

Source: Authors (2015)

Regarding the lifecycle of the business, family and ownership, described by Tagiuri and Davis (1996), this organization can be classified in the start-up phase related to the business life cycle. This can be explained due to the fact that survival is still a main issue in this organization and the business is in its early years.

According to the family life cycle, this organization is in the working together stage as the founder is in his fifties and his sons are in the twenties. Moreover, this business is in the controlling-owner ownership life cycle since the family has $100 \%$ of control of the business. These different lifecycles can be described by the following figure. 


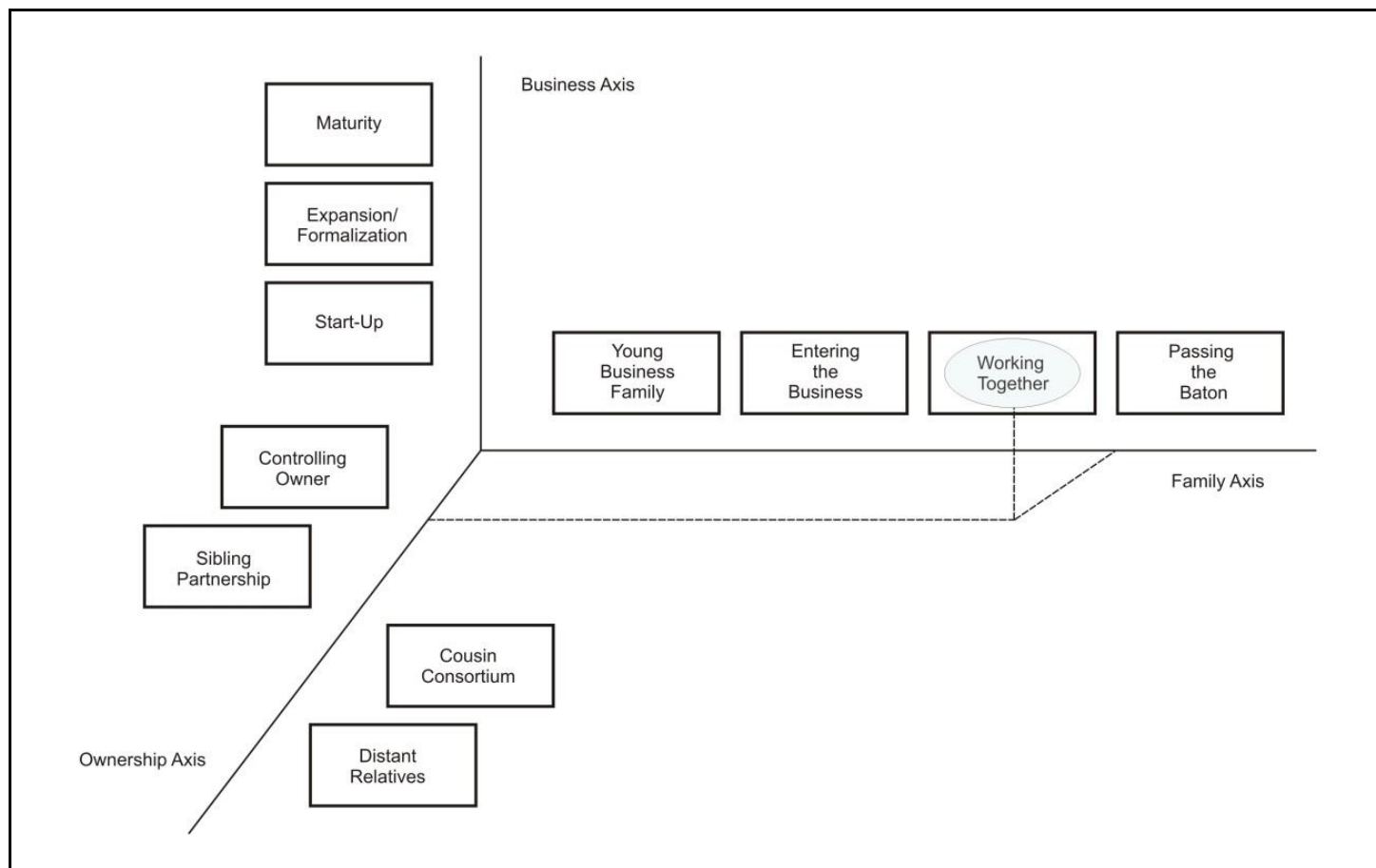

Figure 5 - The Three-Dimensional Developmental Model.

Source: Gersick et al., 1997.

With reference to the governance structure, the firm does not have any governance body such as board of director, family council, shareholders' assembly and shareholder agreement. Moreover there is not any formal organizational structure such as different departments and units. In term of ownership, the family has $100 \%$ control of the workshop. Moreover, the second generation of Family Firm Alfa perceive the business as a family firm.

This perception can be visualized by the statement of the founder of family firm Alfa (verbal information) 'Yes, I consider the business as a family business since all of what happens in the business, it impact family". In line with such thinking the founder's wife (verbal information) states "Yes, I consider the business as a family business since each of the family members is involved or help in a certain way the business."

In relation to succession issues, the owner is interested and also trusts in the second generation to take-over the business, which makes him aware that the firm will remain a family business. However, there is no formal process for succession planning or training program to members of the second generation. 
Regarding family-first, management-first and ownership-first perspective described by Poza (2007), this family firm can not be classified as family first since family member and non family members are equally treated. According to a nonfamily member employee:

I think they are a good work team, they help each other in order to get things done [...]. Besides, the relation that I have with the founder is like if he were my friend [...], also I am confident to talk about my problems with the founder and I know he will help me (verbal information).

It should emphasize that according to Poza (2007), a family firm to be classified in the second type, management-first perspective, must present the following characteristics: (a) working experience of non-family members outside the business in order to be involved in the business; (b) the measurement of performance is the same for family and non-family members; (c) the business is considered by the family as a productive asset which means that there is not a strong commitment of the business to continue to the next generation. This family firm cannot also be in the category of management-first since there is a strong commitment of the business to continue to the next generation as the founder states:

My vision concerning the business is to take advantage of the experience that has been gained until now in order for the workshop be continued in the next generation. This is important for the family since it will provide a source of employment (verbal information)

At last, this organization fits the ownership-first category since this is a typical controlling-owner family which patient capital is one of the main characteristic.

With the objective of getting a better comprehension of the business environment of Family Firm Alfa, was conducted an insight of the network taking into account the main stakeholders of the workshop. First of all, there is only one costumer of this business which is the buses from the transportation company which the founder is a minority shareholder. The entrepreneur of Family Firm Alfa lists as the main stakeholders of the business: auto part shops, tires and oil suppliers, other workshops and independent people offering different types of services. These 
relationships, according to the founder, bring some benefits to the business such as knowledge and information sharing. Furthermore, the owner pointed out that they also provide services and/or help to other workshops:

We have gotten some help or technical advices about how to repair certain part of a bus [...], besides, they can provide us with some spare parts that we cannot find in other place and also they provide us with specific services. This is a reciprocal relationship since we also provide advices and/or services". (verbal information).

The investigation of the structure and the dynamics of family firm Alfa indicate that the relationships are characterized by informal network and the performance of the firm reflects clear objectives around organizational survival. Such elements of structures and dynamics consolidate a unique way of being, that is an organizational culture built on values and subjective elements of a learning process guided by tacit knowledge.

It should be highlighted that these characteristics are typical for small firms, such as the case of family firm Alfa, as Mintzberg (1973) points out that small firms employ the entrepreneurial mode in which the need to survive and to grow are the main goals. Moreover, Burns (2005) states that the informal relationships and the lack of organizational structure are typical of small firms and it should not be view in a negative way.

\section{Organizational culture}

The entrepreneur of the family firm Alfa influences the culture due to his position and long tenure in the business. The values, beliefs and norms are not explicit since there is not any written document regarding these issues. Moreover, family members and non family members can express their opinion without the fear of a negative repercussion.

The organizational culture in a family firm can also be analyzed according to the communication process (BURNS, 2005). In this family firm, the communication process is classified as horizontal where employees who are not family members can 
report directly to the owner and the manager. The language in this organization is characterized as an informal style where family and non family members do not follow any prescribed or official rules or procedures to talk with each other. It should also be mentioned that there is a cooperative environment rather than individualistic.

The founder of family firm Alfa tries to create an entrepreneurial environment since he is constantly encouraging family members to look for new opportunities and be involved in new businesses. This can be related to the fact that the founder was engaged in other start-ups, in the past, and he is still involved in another business.

One of the most typical characteristics of family firm which is a failure culture (HABBERSHON, 2006) can also be realized in this family firm. This was verified in this organization since family and non-family members perceive that the founder would not react in a negative way to the failure of workers involved in entrepreneurial activities. According to one of his son, "if I failed with a business idea, I think my father would try to help me in order to identify the reasons of the failure and encourage me to continue trying with another idea" (verbal information).

The entrepreneur of family firm Alfa considers important that employees be continually learning. The relationship between an entrepreneurial organization and a learning firm is documented in the literature since, according to Burns (2005), an entrepreneurial organization is an empowered learning organization. An employee who is not a family member mentions "the founder is always willing and interested in my learning, whenever there is a course that can be helpful for the workshop, he encourages me to take it" (verbal information).

According to the model presented by Hall, Melin and Nordqvist (2001), the organizational culture in family firm Alfa can be classified as one family member due to the fact that the entrepreneur has a significantly influence in the business, as the founder of family firm Alfa himself states "the manager (non-family member) has the freedom to take decisions without first notice me, but, he knows that decisions that have a considerable impact on the business must have my approval" (verbal information).

It is also implicit since the values, norms and beliefs are not straightforward expressed and open due to the fact that individuals are encouraged to express their ideas and criticisms. Thus, in Figure 6, it represents quadrant number Two. 


\begin{tabular}{|c|c|c|c|c|}
\hline & Closed & Open & Closed & Open \\
\hline Implicit & 1 & $\mathbf{2}$ & 3 & 4 \\
\hline Explicit & 5 & 6 & 7 & 8 \\
\hline
\end{tabular}

Figure 6 - Conceptualization of Family Business Culture.

Source: The authors (2015).

\section{Organizational culture and entrepreneurship}

Hall, Melin and Nordqvist (2001) recommend that the organizational culture must be open and explicit in order to promoter entrepreneurship. Consequently, it can be realized that the organizational culture in this business (implicit and open) does not meet what the same authors recommend that organizational culture should be (explicit and open) in order to foster entrepreneurship.

Due to the fact that the communication process allows the business to communicate and to exchange information more efficiently, the organizational culture has also some positive elements that bring values to the business. Despite the fact that culture of family firm Alfa reflects very much the personality of the founder, it seems that the entrepreneur positively influences the business since he has experiences in other start-ups and this is considered as a critical learning resource and an implicit motivator for family members to be involved in the entrepreneurial process (HABBERSHON, 2006).

In order to understand how the internal resources of the family firm (familiness) can foster the entrepreneurial capabilities described by Habbershon et al. (2003), the resources of the family firm Alfa were investigated. This analyze is described in the Table 1. 
Table 1- Resources and capabilities of the family firm

\begin{tabular}{|c|c|}
\hline Entrepreneurial Capabilities & Resources \\
\hline Opportunity Seeking & $\begin{array}{c}\text { Access to Financial Capital, Business } \\
\text { Portfolio, Network, Tacit Knowledge, } \\
\text { Mentoring Relationship and Decision } \\
\text { Making }\end{array}$ \\
\hline Insight Bursting & Tacit Knowledge \\
\hline Decision Making & $\begin{array}{l}\text { Tacit Knowledge, Culture and Decision } \\
\text { Making }\end{array}$ \\
\hline Bootstrapping & Business Portfolio and Network \\
\hline Venture Financing & $\begin{array}{l}\text { Access to financial Capital, Network and } \\
\text { Culture }\end{array}$ \\
\hline Team Building & Mentoring Relationship and teambuilding \\
\hline Habitual Entrepreneuring & $\begin{array}{l}\text { Mentoring Relationship and Business } \\
\text { Portfolio }\end{array}$ \\
\hline
\end{tabular}

Source: The authors (2015)

It is possible to notice that some resources foster more than one capability. In addition, some capabilities can also be considered as a resource such as team building and decisions making process. The culture in this family firm encourages two capabilities. The first one is decision making. This can be explained by the fact that the failure culture encourages family members to make decisions that involves entrepreneurial activities. Despite the fact that the decision making process is centralized on the founder, the entrepreneurial of family firm Alfa makes decisions that encourages entrepreneurial activities by promoting learning and financing new ventures.

The other capability promoted by the culture is venture financing. One of the distinguish characteristics of family business culture is their propensity to make investments in the long run, which is described, in the literature as patient capital (HABBERSHON, 2006). This fact brings advantages to family firms since they can make investments where short-term investors cannot justify (POZA, 2007). This feature was also noticed in this family firm since the founder expressed that he is willing not just to provide funds for family members, who want to be involved in entrepreneurial activities, but also he is not interested in getting the money back in a short-run. 


\section{Conclusions}

Changing the culture in family business is a special challenge. This can be explained by the fact that "the family is perhaps the most reliable of all social structures for transmitting cultural values and practices across generation" (GERSICK et al., 1997, p. 147) which makes the business behaves very much the same of previous generation. As a consequence, culture of family firms has been characterized as quite inflexible.

As noted, the dominant culture of family firm is the result of beliefs, values and goals rooted in the family and its history (POZA, 2007). The model of Hall, Melin and Nordqvist (2001) can be used to analyze if one family member, in many cases the founder, significantly influences the culture in terms of people feel comfortable to express their criticizes (open) and be aware of the vision (explicit).

Family firm Alfa illustrates an organization that despite the fact that there is not an explicit vision and it is managed by a founder with a quite strong personality (one family member), it has developed quite well since the leader promotes learning and fosters other individuals to express their ideas. However, in order for firms to grow and create the positive conditions for change that promotes entrepreneurship, it could be recommend a governance structure in which family members can discuss the business and owner issues and, as a consequence, other members than just the founder could significantly influence the family firm Alfa.

Despite the fact that this is a small family firm, a Family Council can help this firm, to preserve values, harmony, long term commitment to the business and manage firm resources in a way to create sustainable competitive advantage due to the systematic interaction and commitment of family members with the prosperity of the business (POZA, 2007; HABBERSHON; WILLIAM, 1999).

Moreover, in order for the culture of this organization helps the firm to be more involved in entrepreneurial activities, we recommend the family firm Alfa be engaged in the following activities:

a) The organization should be continually involved in looking for new opportunities which can be done by developing an entrepreneurial culture that clearly 
expresses and encourages an entrepreneurial behaviour, through its values and beliefs. This kind of activity is relevant since the culture was not a resource related to opportunity seeking;

b) The organization should encourage its members to develop relationships with other organizations when they believe that it could add value to the business since, nowadays, the only client of the workshop is the buses of the transportation services. We can visualize potential clients that could be positive for the workshop to develop relationships with such as bus owners, government, tourism agencies and schools that could need transportation services for their citizens, tourists and students;

c) The development of an explicit vision that engages and motivates family and non-family members towards a common goal. This aspect is at the utmost importance since the vision is a key element of both entrepreneurship and leadership (Burns, 2005);

d) The firm should systematically analyze, check and, if it is necessary, develop its internal resources (familiness) in order for them to match its capabilities with the requirements from the external environment to capture new opportunities.

The empirical observation and analysis of this study support the conclusion from the literature that family businesses present relatively strong organizational culture in which entrepreneurship is a radical change and a special challenge due to the strong emotions involved in this process.

The analysis of the external environment is a limitation that could have impacted the results of this study. Habbershon (2006) has mentioned that the external environment shapes the norms, values and beliefs of organizations. Moreover in order to classify family firm as entrepreneurial organization, it is necessary to take into consideration the nature of the environment in which the organization operates. In other words, it is important to analyze if the firm works on a dynamic or stable, complex or simple environment. This can also be a topic for future researches in this area.

Another topic of future research consists on the fact that the model of Hall, Melin and Nordqvist (2001) is also applied to analyze the dynamic nature of organizational culture. In this way, it is recommended a study that investigates how 
the organizational culture changes, according to the variables mentioned by this model, as the firm is getting old and increases its size.

\section{References:}

ANDERSON, R.C.; REEB, D.M. Founding-family ownership and firm performance: Evidence from the S\&P 500. Journal of Finance, v. 58, n. 58, p. 1301-1328, 2003.

BARDIN, L. Análise de conteúdo. Lisboa: Edições 70, 2009.

BARNETT, T.; KELLERMANNS, F.W. Are we family and are we treated as family? Nonfamily employees' perceptions of justice in the family firm. Baylor University, v. 30 , n. 6, p. 837-854, 2006.

BARNEY, J.B. Firm resources and sustained competitive advantage. Journal of Management, Stillwater, v. 17, n.1, p. 99-120, 1991.

BARRINGER, B.R.; IRELAND, R.D. Entrepreneurship: successfully launching new ventures. Upper Saddle River: Pearson Prentice Hall, 2006.

BORGES, A. F.; BRITO, M. J.; LESCURA, C. O campo de pesquisas sobre empresas familiares no Brasil: análise da produção científica no período de 19972009. Revista Eletrônica de Gestão Organizacional, v. 10, n. 3, p. 595-622, 2012.

BURNS, P. Corporate entrepreneurship: building an entrepreneurial organization. New York: Palgrave MacMillan, 2005.

CARLOCK, R. S.; WARD, J. S. Strategic planning for the family business: parallel planning to unify the family and business. NewYork: Palgrave, 2001.

CHUA, J. H.; CHRISMAN, J. J.; SHARMA, P. Succession and nonsuccession concerns of family firms and agency relationships with nonfamily managers, Family Business Review, v. 16, n. 2, p. 89-107, 2003.

CORNWALL, J. R.; PERLMAN, B. Organizational Entrepreneurship. Homewood: Irwin, 1990.

DAVIS, P.; STERN, D. Adaptation, survival, and growth of the family business: An integrated system perspective. Human Relation, v. 34, n. 4, p. 207-222, 1980.

DYER, G. W. The family: The missing variable in organizational research. Entrepreneurship Theory and Practice, v. 27, n. 4, p. 401-416, 2003. 
EUROPEAN COMMISSION ENTERPRISE AND INDUSTRY DIRECTORATE. Overview of Family Business Relevant Issues: Research, Networks, Policy Measures and Existing Studies, 2009. Retrieved from: http://ec.europa.eu/enterprise/policies/sme/promoting-entrepreneurship/familybusiness/family_business_expert_group_report_en.pdf

GARCIA-ALVAREZ, E.; LOPEZ-SINTAS, J.; SALDANA GONZALVO, P. Socialization patterns of successors in first- to second generation family businesses. Family Business Review, v. 15, n. 3, p. 189-203, 2002.

GERSICK, K. E.; DAVIS, J. A.; HAMPTON, M. M.; LANSBERG, I. Generation to Generation. Washington: Library of Congress Cataloging-in-Publication Data, 1997.

GHAURI, P.; GRØNHAUG, K.; KRISTIANSLUND, I. Research methods in business studies: A practical guide. Prentice Hall. Hemel Hempstead, 1995.

GRANT, R.M. The Resource-Based Theory of Competitive Advantage: Implications for Strategy Formulation. California Management Review, v. 33, n. 3, p. 114-135, 1991.

GRZYBOVSKI, D., LIMA, J. Conceito de família e o dilema metodológico nos estudos sobre empresas familiares. In.: III ENCONTRO DE ESTUDOS ORGANIZACIONAIS - ENEO, 2004, Atibaia. Anais... Atibaia, 2004.

HABBERSHON, T.G. The Family as a Distinct Context for Entrepreneurship. Praeger Perspectives on Entrepreneurship, v. 30, n. 6, p. 879-886, 2006.

HABBERSHON, T. G.; WILLIAMS, M. L.; MACMILLAN, I. C. A unified systems perspective of family firm performance. Journal of Business Venturing, v.18, n.2, p. 451-465, 2003.

HABBERSHON, T.G.; PISTRUI, J.; MCGRANN, M. Enterprising families: Mindset and methods for wealth acceleration in a dynamic marketplace. Pennsylvania: Snider Entrepreneurial Center, 2001.

HABBERSHON, T. G.; WILLIAMS, M. L. A resource-based framework for assessing the strategic advantage of family firms. Family Business Review, v. 12, n. 1, p. 126, 1999.

HALL, A., MELIN, L.; NORDQVIST, M. Entrepreneurship as radical change in the family business: exploring the role of cultural patterns. Family Business Review, v. 14 , n. 3, p. 193-208.

HARVEY, M.; EVANS, R. E.. Family businesses and multiple levels of conflict. Family Business Review, v. 7, n. 4, p. 331-348, 1994.

DANDA, G. J. N.; GRZYBOVSKI, D. Understanding organizational culture in a small family firm. Revista de Empreendedorismo e Gestão de Pequenas Empresas, v.4, n.2, 2015 
HOLLANDER, B. S.; ELMAN, N. S. Family-owned businesses: An emerging field of inquiry. Family Business Review, v. 1, n. 2, p. 145-164, 1998.

HOY, F.; VESSER, T. T. Emerging business, emerging field: Entrepreneurship and the family firm, Entrepreneurship Theory and Practice, v. 19, n. 1, p. 9-24, 1994.

JOHANNISSON, B. The social construction of the disabled and unfashionable family business. In: Nordic Conference on Small Business Research, Tromsö, Norway, 2004.

KELLY, L.; ATHANASSIOU, N.; CRITTENDEN, W. Founder centrality and strategic behavioral the family-owned firm; Entrepreneurship Theory and Practice, v. 25, n. 2, p. 27-42, 2000.

KENYON-ROUVINEZ, D.; WARD, J. L. Family business key issues. Hampshire: Palgrave MacMillan, 2005.

LIN, W. Family ownership and internationalization processes: Internationalization pace, internationalization scope, and internationalization rhythm. European Management Journal, v. 30, n. 1, p. 47-56, 2012.

LYMAN, A. R. Customer service: Does family ownership make a difference? Family Business Review, v. 4, n. 3, p. 303-324, 1991.

LOPES, F. T.; CARRIERI, A.; SARAIVA, L. A. S. Relações entre poder e subjetividade em uma organização familiar. Organizações \& Sociedade, v. 20, n. 65 , p. 225-238, 2013.

MAKADOK, R. Toward a synthesis of the resource-based and dynamic-capability views of rent creation. Strategic Management Journal, v. 22, n.5, p. 387-402, 2001.

MARTINS, A.; MACCARI, E. A.; CAMPANARIO, M. A.; ALMEIDA, M. I. R. Empresa familiar e as dificuldades enfrentadas pelos membros da terceira geração. Revista de Ciências da Administração, v. 10, n.22, p. 30-54, 2008.

MCCONAUGHY, D. Family CEOs vs. Nonfamily CEOs in the family controlled firm: An examination of the level and sensitivity of pay to performance. Family Business Review, v. 13, n. 2, p. 121-131, 2000.

MELIN, L. Salö F. Svenska Familjeföretag inte på utdöende; Second Option, Stcokolm, 2009.

DANDA, G. J. N.; GRZYBOVSKI, D. Understanding organizational culture in a small family firm. Revista de Empreendedorismo e Gestão de Pequenas Empresas, v.4, n.2, 2015 
MINTZBERG, H. Strategy: making in three modes. California Management Review. v. 16, n. 2, 1973.

MORRIS, M. H.; KURATKO, F. D. Corporate Entrepreneurship. New York: Harcourt College Publishers, 2002.

NORDQVIST, M.; MELIN, L. The dynamics of family firms: an institutional perspective on corporate governance and strategic change. In: FLETCHER, D. (Ed.) Understanding the Small Family Firm. London: Routledge Studies in Small Business, 2002.

OLSON, P. D.; ZULKER, V. S.; DANES, S. M.; STAFFORD, K.; HECK, R. K. Z.; DUNANC, K.A. Impact of family and business on family business sustainability. Journal of Business Venturing, v.18, n. 5, p. 639-666, 2003.

POZA, E. J. Family Business. New York: Thomson South-Western, 2007.

RÖMER-PAAKKANEN, T. Family Entrepreneurship in a Retail Chain: the Grocer's Household-Enterprise Complex. Helsinki: Universtiy of Helsinki, 2002

SCHEIN, E. H. The role of the founder in creating organizational culture. Family Business Review, v. 8, n. 3, p. 221-238, 1995.

SHARMA, P. An overview of the field of family business studies: current status and directions for the future. Family Business Review, v. 17, n. 1, p. 1-36, 2004.

SHARMA, P.; NORDQVIST, M. A Classification Scheme for Family Firms: From Family Values to Effective Governance to Firm Performance; In: TAPIES, J.; WARD, J. Family values and value creation. Palgrave Macmillan, 2008.

SILVA JÚNIOR, A.; SILVA, P. O. M; SILVA, A. R. L. Sistema de valores e implicações na governança corporativa em um grupe empresarial familiares. Organizações \& Sociedade, v. 20, n. 65, p 239-260, 2013.

SIMON, D. G.; HITT, M. A. Managing resources: linking unique resources, management, and wealth creation in family firms. Entrepreneurship Theory and Practice, v. 27, n.4, p.339-358, 2003.

SWARTZ, S. The challenges of multidisciplinary consulting to family-owned businesses. Family Business Review, v. 2, n. 4, p. 329-339, 1989.

TAGIURI, R.; DAVIS, J. A. Bivalent attributes of the family firm. Family Business Review, v. 9, n. 2, p. 199-208, 1996. 
UCBASARAN, D., WESTHEAD, P.; WRIGHT, M. Habitual Entrepreneurs. Oxford : Oxford University, 2009.

WARD, J. L. Growing the family business: Special challenges and best practices. Family Business Review, v. 10, n.4, p. 323-337, 1997.

WELMAN, C.; KRUGER, F.; MITCHELL, B. Research methodology. Capetown: Oxford University, 2005.

WERNERFELT, B. A resource-based view of the firm. Strategic Management Journal, v. 5, n. 2, p. 171-180, 1984.

WESTHEAD, P.; COWLING, M. Family firm research: the need for a methodological rethink. Entrepreneurship Theory and Practice, v. 23, n.1, p. 31-56, 1998.

WIKLUND, J. Small firm growth and performance: entrepreneurship and beyond. Jönköping International Business School: Jönköping, 1998.

ZAHRA, S.A.; HAYTON, J. C.; SALVATO, C. Entrepreneurship in family vs. nonfamily firms: A resource-based analysis of the effect of organizational culture. Entrepreneurship Theory and Practice, v. 28, n. 4, p.363-381, 2004. 